\title{
Pendekatan Inovatif dalam Mengantisipasi Penyebaran COVID-19: Laporan KKN Tematik COVID-19 2020.
}

\author{
Cucuk Budiyanto $^{1}$, Nur Alvi Nikmah ${ }^{2}$, Ayu Cahyaningsih ${ }^{3}$, Kun Afifah ${ }^{4}$ \\ ${ }^{1}$ Informatics Education Department, The Faculty of Teacher Training and Education Universitas \\ Sebelas Maret, ${ }^{2}$ Art Education, The Faculty of Teacher Training and Education Universitas \\ Sebelas Maret, ${ }^{3}$ Elementary Teacher Training, The Faculty of Teacher Training and Education \\ Universitas Sebelas Maret, ${ }^{4}$ Accounting Education, The Faculty of Teacher Training and \\ Education Universitas Sebelas Maret \\ Corresponding email: cbudiyanto@staff.uns.ac.id
}

\begin{abstract}
The Covid-19 pandemic has spread to almost all over the world with a high death rate, causing public anxiety. At the beginning of the pandemic, the community did not yet have an adequate understanding of what and how the virus spreads, therefore bring the pandemic into communities' attention is the most important effort to do. Through the Covid-19 UNS 2020 Batch 2 Community Service Program Join Project which was held in Kebumen Regency and Magelang Regency, Central Java, students participated in offering solutions to provide understanding through an innovative and more personal approach. The COVID19 KKN agenda provided the appropriate information via mobile devices, videos, posters, and activities that mitigate the spread of the virus while keep the community members remain productive.
\end{abstract}

Keywords: COVID-19; clean and healthy lifestyle; education; health protocol. 


\begin{abstract}
ABSTRAK
Pandemi Covid-19 telah menyebar hampir ke seluruh dunia dengan tingkat kematian yang tinggi sehingga menimbulkan kecemasan kepada masyarakat. Di awal pandemic, masyarakat belum memiliki pemahaman yang memadai tentang apa dan bagaimana penyebaran virus tersebut, sehingga diperlukan sosialisasi dan pendampingan kepada masyarakat. Melalui kegiatan KKN Covid-19 UNS 2020 Batch 2 yang dilaksanakan di Kabupaten Kebumen dan Kabupaten Magelang, Jawa Tengah, mahasiswa berpartisipasi menawarkan solusi pemberian pemahaman melalui pendekatan yang inovatif dan lebih personal. Program kerja KKN COVID-19 memberikan informasi melalui perangkat telepon cerdas, video, maupun kegiatan yang mengurangi aktifitas masyarakat di luar rumah tetapi tetap bisa produktif selama pandemi.
\end{abstract}

Kata kunci: COVID-19; edukasi; perilaku hidup bersih dan sehat; protocol kesehatan.

DOI: https://dx.doi.org/10.20961/dedikasi.v2i2.45881

\title{
PENDAHULUAN
}

Kasus pneumonia misterius yang pertama kali dilaporkan di Wuhan pada bulan Desember 2019 menandai berjangkitnya virus yang kemudian dikenal sebagai corona virus desease secara global. Sumber penularan kasus ini masih belum diketahui pasti, tetapi kasus pertama dikaitkan dengan pasar ikan di Wuhan. Virus ini dapat ditularkan dari manusia ke manusia dan telah menyebar secara luas di China dan lebih dari 190 negara dan teritori lainnya. Virus tersebut diumumkan oleh WHO bernama Coronavirus Disease (COVID-19).

Di Indonesia, COVID-19 pertama dilaporkan tanggal 2 Maret 2020 sejumlah dua kasus. Data 31 Maret 2020 menunjukkan kasus yang terkonfirmasi berjumlah 1.528 kasus dan 136 kasus kematian. Tingkat mortalitas COVID-19 di Indonesia sebesar 8,9\%, angka ini merupakan yang tertinggi di Asia Tenggara. Di tengah masyarakat, kesadaran untuk senantiasa mentaati himbauan pemerintah dalam pencegahan dan penanganan kasus corona pun terhitung masih rendah. Masyaraat masih banyak yang mengbaikan protokol social \& physical distancing sehingga lonjakan kasus Covid-19 ini masih tinggi.

Indonesia hingga saat ini masih bergelut melawan virus Corona, sama dengan negara lain di dunia. Covid-19 ditetapkan oleh Organisasi Kesehatan Dunia atau WHO menjadi sebuah pandemic sehingga mengakibatkan penyakit ini menjadi salah satu permasalahan di tingkat global (WHO, 2020). Kondisi tersebut membuat pemerintah pusat maupun daerah sampai saat ini terus berupaya untuk 
membuat kebijakan guna menekan angka penyebaran virus Covid - 19. Kebijakan pemerintah diantaranya yakni himbauan menjaga jarak, mengurangi kerumunan atau perkumpulan warga, perilaku hidup bersih dan sehat (PHBS), belajar dari rumah, bekerja dari rumah (Work From Home), serta beribadah di rumah. Di sisi lain, kurangnya kesadaran masyarakat terhadap pentingnya pencegahan penyebaran wabah virus corona menyebabkan kurangnya kepedulian warga terhadap bahayanya paparan Covid-19 dan menyepelekan berbagai protokol kesehatan yang seharusnya diterapkan.

Selain isu kesadaran masyarakat, isolasi atau karantina mandiri dan kebijakan untuk bekerja / sekolah dari rumah ditengarai menyebabkan kejenuhan pada anggota masyarakat. Apalagi informasi-informasi negatif tentang Covid-19 yang terus menyebar menyebabkan sesorang hidup di bawah rasa takut dan kekhawatiran. Hal tersebut apabila seseorang tidak bisa memanajemen kesehatan mentalnya, maka akan berdampak stres. Padahal sebagaimana dilansir dari Liputan6.com kesehatan mental tersebut berpengaruh terhadap sistem imun, seseorang yang stress dapat menurunkan sistem imun. Kemudian sistem imun yang rendah akan dapat mudah terpapar penyakit. Maka sesekali perlu adanya refreshing yang mampu mengalihkan pikiran mengenai Covid-19. Sebenarnya banyak refresing yang dapat dilakukan oleh seseroang.

\section{METODOLOGI PENELITIAN}

Dalam pelaksanaan program kerja yang telah dibuat dilakukan secara langsung ataupun tidak langsung. Pelaksannan program secara langsung dilakukan dengan terjun langsung kelapangan atau bertemu langsung dengan warga sedangkan cara tida langsung yaitu dengan pemberian pemahaman dan edukasi secara daring dengan memnfaatkan grup What's App warga dusun serta media sosial pribadi yang dapat diakses dengan mudah oleh masyarakat.

Berbagai informasi dibuat menjadi beberapa bentuk mulai dari video, gambar sampai dengan artikel yang dikemas secara ringkas. Publikasi informasi juga menggunkan berbagai cara seperti peng-upload-an pada laman Youtube pribadi, media sosial seperti instagram, What's App hingga pemasangan secara langsung beberapa poster dan benner di lingkungan desa. Pembagian beberapa perlengkapan pendukung PHBS juga dilakukan seperti embagian masker kain dan Hand Sanitzer.

\section{HASIL DAN PEMBAHASAN}

Berbagai program kerja yang dibuat dalam kegiatan KKN Covid-19 UNS ini ditujukan kepada Dusun Sabrangrowo, Borobudur, Magelang, khususnya 
warga RT 02/RW 09. Setiap kegiatan yang dilaksanakan mendapatkan respon dan dukungan yang baik oleh warga desa dan pengurus desa.

1. Edukasi Pentingnya Penggunaan Masker Kain dan Membuat Sendiri Masker Kain Secara Manual.

Berawal dari keresahan ketua RT setempat yang mengatakan bahwa masih banyak warga desa belum memiliki kesadaran untuk memakai masker kain saat beraktivitas diluar rumah menjadikan program kerja ini fokus utama dalam pelaksanaan kegiatan KKN Covid-19 didusun Sabrangrowo. Edukasi petingnya penggunaan masker kain dimulai dengan pembuatan video edukasi mengenai informasi-informasi mengenai masker yang selanjutnya diunggang ke laman youtube pribadi. Selanjutnya dilakukan sosialisasi secara daring kewarga dengan memanfaatkan grup What,s App desa serta pembagian link youtube yang telah dibuat.

Sosialisasi yang telah dilaksanakan, dilakukan tindaklanjut dengan edukasi pembuatan masker kain sendiri. Edukasi ini diawali pembagian bahan dan alat pembuatan masker kain berupa 2 helai kain katun, benang, dan jarum jahit. Selanjutnya untuk cara pembuatan masker kain diberikan dengan pembuatan video tutorial pembuatan masker kain dan diupload ke akun youtube pribadi lalu dibagikan kedalam grup what's app. Edukasi pembuatan masker kain pribadi ini dengan maksud agar warga desa dapat membuat masker kain sendiri sehingga tidak ada alasan tidak menggunkan masker kain karna hanya memiliki masker kain yang terbatas.

\section{Pembuatan Video Edukasi}

Video edukasi dibuat dengan berbagai konten. Pembuatan video ini dilakukan dengan maksud agar berbagai informasi yang ingin diberikan kepada warga akan memudahkan warga desa dalam memahami dan menerima informasi-informasi tersebut. Beberapa video yang telah dibuat berupa edukasi penggunaan masker kain yng baik dan benar, cara melakukan cuci tangan dan alasan mengapa perlu melakukan cuci tangan, tutorial pembuatan masker kain pribadi, dan tutorial pembuatan hand sanitizer alami.

Video-video tersebut selanjutnya diunggah ke akun youtube pribadi dan selanjutnya dibagikan kepada warga desa dan lainnya dengan memnafaatkan media sosial seprti what's app, Instagram dan Facebook. Pembagian link youtube kepada warga desa disertai dengan sosialisasi dalam bentuk tulisan agar dapat lebih memahamankan warga mengenai hal yang ingin disampaikan.

Salah satu tindaklanjut dari pembuatan video tutorial pembuatan hand sanitizer adalah dilakukan pembagian Hand Sanitizer kapada warga 
untuk memotivasi warga menjaga kebersihan tangan sesuai anjuran pemerintah.

\section{Pembuatan dan Publikasi Poster-Poster dan Benner Edukasi.}

Poster-poster edukasi dibuat dengan maksud untuk memberikan informasi-informasi terkini kepada warga. Konten yang dibuat didasarkan pada sumber-sumber terpercaya seperti akun Instagram Kementrian Kesehatan Indonesia, WHO dan lain sebagainya. Poster-poster yang dibuat dipublikasikan secara daring dan luring. Publikasi secara daring dilakukan menggunakan media sosial What's App, Instagram dan Facebook lalu untuk luring dilakukan dengan mencetak poster lalu ditempel dibeberapa tempat strategis di lingkungan desa.

Pembuatan dan pemasangan banner di lingkungan desa sebagai anjuran serta tindak lanjut pada program sosialisasi penggunaan masker kain. Konten banner yang dibuat dengan memanfaatkan foto-foto warga desa yang telah membuat dan memakai masker kain mereka sendiri. Hal ini dimaksutkan agar warga lebih termotivasi untuk memakai masker kain saat beraktivitas diluar rumah.

\section{Pembagian Bibit Sayur}

Pembagian bibit sayur dilakukan kepada seluruh warga desa yang menginginkan bibit sayur. Bibit sayur yang dibagikan sebanyak 150 bibit dengan 3 jenis sayur yaitu cabai, kangkung dan terong. Pembagian bibit sayur dilakukan sebagai bentuk respon terhadap keluhan masyarakat mengenai mahalnya harga bahan makanan ditambah dengan berkurangnya pengahsilan masyarakat akibat adanya pandemi. Diharapkan pembagian bibit sayur tersebut dapat sidikit membantu warga desa untuk kesediaan summber pangan dan memberikan sedikit kegiatan kepada warga desa untuk mengisi waktu luang selama Dirumah Aja.

\section{KESIMPULAN}

Penanaman pemahaman warga mengenai Covid-19 DI WILAYAH KABUPATEN KEBUMEN DAN MAGELANG dilakukan dengan Sosialisasi edukasi pentingnya penggunaan masker kain dan membuat sendiri masker kain secara manual, Pembuatan Video, pembuatan dan publikasi poster-poster dan benner edukasi. Berbagai kegiatan yang diberikan kepada warga diterima dengan baik serta memberikan dampak yang baik pula. Respon tersebut dilihat dengan banyaknya warga desa yang mulai sadar untuk menggunakan masker kain saat 
beraktivitas diluar rumah lalu cerita dari warga desa yang membawa hand sanitizer yang telah dibagikan saat bepergian.

\section{ACKNOWLEDGMENT}

Kegiatan Pengabdian Kepada Masyarakat ini dilaksanakan dengan dukungan dari program KKN COVID-19 tahun Anggaran 2020.

\section{DAFTAR PUSTAKA}

COVID-19 - Kab. Magelang - Kabupaten Magelang. Kabupaten Magelang Tanggap COVID-19. Pusat Informasi Seputar COVID-19 di Kabupaten Magelang. https://infocorona.magelangkab.go.id. Diakses 9 Juli 2020 pukul $01.00 \mathrm{WIB}$.

UNICEF, IRC, \& WHO. 2020. Key Messages and Actions for Covid-19 Prevention and Control in Schools. Sumber:https://www.who.int/docs/default-source/coronaviruse/keymessages-and-actions-for-covid-19-prevention-and-control-in-schools-march2020.pdf?sfvrsn=baf81d52_4. Diakses 15 Juli 2020 pukul 20.24 